\title{
Effect of Selected Yogic Practices and Aerobic Dance on Health Related Physical Fitness Variables Among Nicobari Women Students
}

\author{
S.Usha Rani ${ }^{a}$ and Satyander Pal Sing ${ }^{b}{ }^{*}$ \\ ${ }^{a}$ Guest Lecturer, ${ }^{b}$ Assistant Professor, Dept. of Physical Education, JNRM College, Port \\ Blair, Andaman \& Nicobar Island- 744106, India \\ *Corresponding Author Ph: 03192240 482; Email: satyanderpalsingh@ gmail.com
}

DOI: $\mathbf{1 0 . 2 6 5 2 4 / 1 3 4 2 0}$

\begin{abstract}
The purpose of the study was to find out the effect of selected yogic practices and Aerobic dance on health related physical fitness variables among Nicobari women students. Seventy-five students were selected from JNRM College, Port Blair, Andaman\& Nicobar Island. The age of the subjects ranged from 18 to 22 years. The selected subjects were divided into two experimental groups and one control group by random. Group I underwent Yogic practices in selected asanas and pranayama; Group II underwent Aerobic dance and Group III acted as Control Group for three alternate days in a week for a period of six weeks. The dependent variables selected for this study were Cardio vascular endurance, Muscular strength/endurance, Flexibility and Body composition. The dependent variables namely Cardio Vascular Endurance measured by Cooperes 1 -mile run/walk test, Flexibility measured by Sit and Reach Test, Muscular Strength/ Endurance measured by Bent Knee Sit ups and Body Composition measured by Skin fold caliper. The data were collected from each subject before and after the training period and statistically analyzed by using dependent „t" test and analysis of covariance (ANCOVA). It was found that Aerobic dance group was found to be better in improving cardio vascular endurance and muscular strength/endurance when compared to the yogic practices group.Yogic practices group was found to be better in improving flexibility when compared to the aerobic training group.Both yogic practices and aerobic dance groups were developed the body composition equally.
\end{abstract}

Key Words: Yogic practices, Aerobic Dance, Muscular Endurance, Cardiovascular Endurance, Body composition

\section{Introduction}

Yoga has a hoary past. The importance for the spiritual attainment has been recognized throughout the ages by all the systems of Indian philosophy. There is no doubt that the essence of yoga has been considered in the spiritual upliftment of man. One may question as to how then yoga is related to the physical education and whether yoga will not be pulled down from its highest pedestal in doingthis. It is necessary, therefore, to clear the concepts of yoga and physical education first [1, 2].

The word "aerobics" is a common terminology primarily used to refer specifically to synchronize systematic movements of one se body. During the last decade women wanted to get the benefit of the aerobic workout and hence associated with jogging and searched for other way of exercises besides disliking running by themselves. This spawned in past the aerobics enthusiasm. Aerobics combined with an aerobic workout allowing them to enjoy and thus keep them exercising long enough to improve their aerobic capacity.

Fitness improves general health and it is essential for full and vigorous living. The physical fitness over a long span and examination of the same reflect the status of health. Physical examination assesses the growth pattern and functional efficiency of sensory and motor organs, functional efficiency of the body in terms of strength, Cardio vascular endurance, flexibility, speed, agility, and balance and neuro muscular co-ordination [3-5].

The Nicobarese are of Mongloid Stock are a large population of over 27,000 (2001 census). They are horticulturist and pig-herders inhabiting large permanent villages mostly close to seashore. They are not divisible into tribes, but there are distinctions, chiefly territorial. Thus they may be fairly divided into six groups: the people of Car Nicobar, Chowra, Teressa with Bompoka, the Central Group, the Southern Group and the single inland tribe of the Shompen on Great Nicobar. The differences to be observed is language, customs, manners and physiognomy of the several groups may, with some confidence, be referred to habitat and the physical difficulties of communication [6-8].

\section{Methodology}

Seventy-five students were selected from JNRM College, Port Blair, Andaman \& Nicobar Island. The age of the subjects ranged from 18 to 22 years. The selected subjects were divided into two experimental groups and one control group by random. During the training period the experimental groups underwent their respective training program in addition to their regular program of the course of study. Group I underwent Yogic practices in selected asanas and pranayama; Group II underwent Aerobic dance and Group III acted as Control Group for three alternate days in a week for a period of six weeks. The dependent variables selected for this study were Cardio vascular endurance, Muscular strength/endurance, Flexibility and Body composition. The dependent variables namely Cardio Vascular Endurance measured by Cooper"s 1mile run/walk test, Flexibility measured by Sit and Reach Test, Muscular Strength/ Endurance measured by Bent Knee Sit ups and Body Composition measured by Skin fold caliper.

The duration of training session in the six weeks was between 30 to 60 minutes approximately, including warming up and cooling down. Group III acted as control. They did not participate in any specific training on par with experimental group. All the subjects involved in this study were carefully monitored throughout the training program to be away from injuries. They were questioned about their health status throughout the training program. None of them reported any injuries. However, muscle soreness appeared in the earlier period of the training program and was reduced in due course. 
The training program scheduled with the duration and load was based on the results of the pilot study. The training program was carried out for a period of six weeks and the schedule was presented in Table I.

TABLE - I

Training Schedule For Yogic Practices And Aerobic Dance

\begin{tabular}{|c|c|c|c|}
\hline Days & Duration & Yogic practices & Aerobic Dance \\
\hline $\begin{array}{l}\text { Monday } \\
\text { Wednesday } \\
\text { Friday }\end{array}$ & $1^{\text {st }} \& 2^{\text {nd }}$ Weeks & $\begin{array}{l}10 \mathrm{mts} \text { - Stretching } \\
20 \mathrm{mts} \text { - Asanas } \\
10 \mathrm{mts}-\text { ujjayi pranayama } \\
\text { 10mts- Relaxation }\end{array}$ & $\begin{array}{l}10 \mathrm{mts} \text { - Warm-Up } \\
\text { 35mts- Low impact Aerobic dance } \\
\text { 5mts - Relaxation }\end{array}$ \\
\hline $\begin{array}{l}\text { Monday } \\
\text { Wednesday } \\
\text { Friday }\end{array}$ & $3^{\text {rd }} \& 4^{\text {th }}$ Weeks & $\begin{array}{l}\text { 10mts - Stretching } \\
25 \mathrm{mts}-\text { Asanas } \\
15 \mathrm{mts} \text { - ujjayi pranayama } \\
\text { 10mts- Relaxation }\end{array}$ & $\begin{array}{l}10 \mathrm{mts}-\text { Warm-Up } \\
40 \mathrm{mts}-\text { High impact Aerobic } \\
\text { dance } \\
5 \mathrm{mts} \text { - Relaxation }\end{array}$ \\
\hline $\begin{array}{l}\text { Monday } \\
\text { Wednesday } \\
\text { Friday }\end{array}$ & $5^{\text {th }} \& 6^{\text {th }}$ Weeks & $\begin{array}{l}\text { 10mts - Stretching } \\
25 \mathrm{mts}-\text { Asanas } \\
15 \mathrm{mts} \text { - ujjayi pranayama } \\
\text { 10mts- Relaxation }\end{array}$ & $\begin{array}{l}10 \mathrm{mts} \text { - Warm-Up } \\
45 \mathrm{mts}-\text { step Aerobic dance } \\
5 \mathrm{mts} \text { - Relaxation }\end{array}$ \\
\hline
\end{tabular}

\section{Results and Discussion}

The influence of independent variables on each criterion variables were analyzed and presented below. The mean and dependent , ${ }^{\mathrm{te}}$ test values on cardio vascular endurance of yogic practices, aerobic Dance and control groups have been analyzed and presented in Table II.

TABLE - II

Summary Of Mean And Dependent „„te Test For The Pre And Post Test On Selected Variables Of Experimental And Control Groups

\begin{tabular}{|c|c|c|c|c|}
\hline Variables & Mean & $\begin{array}{l}\text { Yogic practices } \\
\text { Group }\end{array}$ & $\begin{array}{l}\text { Aerobic training } \\
\text { Group }\end{array}$ & Control Group \\
\hline \multirow[t]{3}{*}{$\begin{array}{l}\text { Cardiovascular } \\
\text { Endurance }\end{array}$} & Pre test Mean & $\begin{array}{l}450.56 \\
\pm 9.70\end{array}$ & $\begin{array}{l}449.60 \\
\pm 6.91\end{array}$ & $\begin{array}{ll}442.80 & \pm \\
6.82 & \end{array}$ \\
\hline & Post test Mean & $\begin{array}{l}427.33 \\
7.53\end{array}$ & $\begin{array}{l}403.83 \\
\pm 7.03\end{array}$ & $\begin{array}{l}446.20 \\
7.31\end{array}$ \\
\hline &, $\mathrm{t}^{\mathrm{ee}}$ Test & $10.23^{*}$ & $2.44^{*}$ & $\mathbf{1 . 0 3}$ \\
\hline \multirow[t]{3}{*}{ Muscular Endurance } & Pre test Mean & $\begin{array}{l}24.16 \\
1.65\end{array}$ & $\begin{array}{l}24.08 \\
2.66\end{array}$ & $\begin{array}{l}25.00 \\
3.24\end{array}$ \\
\hline & Post test Mean & $\begin{array}{l}26.64 \\
2.13\end{array}$ & $\begin{array}{l}28.12 \\
2.61\end{array}$ & $\begin{array}{l}24.96 \\
3.44\end{array}$ \\
\hline &, $\mathrm{t}^{\mathrm{ee}}$ Test & $6.957^{*}$ & $19.81 *$ & 0.125 \\
\hline \multirow[t]{3}{*}{ Flexibility } & Pre test Mean & $\begin{array}{l}25.76 \\
1.92\end{array}$ & $\begin{array}{l}25.20 \\
2.75\end{array}$ & $\begin{array}{l}25.72 \\
3.19\end{array}$ \\
\hline & Post test Mean & $\begin{array}{l}29.72 \\
2.64\end{array}$ & $\begin{array}{l}27.40 \\
3.11\end{array}$ & $\begin{array}{l}25.76 \\
3.14\end{array}$ \\
\hline &, $\mathrm{t}^{\mathrm{ee}}$ Test & $10.23 *$ & $11.00 *$ & 0.137 \\
\hline \multirow[t]{3}{*}{ Body Composition } & Pre test Mean & $\begin{array}{l}26.28 \\
0.51 \\
\end{array}$ & $\begin{array}{l}26.31 \\
0.61 \\
\end{array}$ & $\begin{array}{l}26.59 \\
1.17 \\
\end{array}$ \\
\hline & Post test Mean & $\begin{array}{l}24.70 \\
0.16 \\
\end{array}$ & $\begin{array}{l}24.32 \\
0.30 \\
\end{array}$ & $\begin{array}{l}26.52 \\
1.14 \\
\end{array}$ \\
\hline & ,t, $\mathrm{te}^{\mathrm{ee}}$ Test & $13.50 *$ & $14.77 *$ & 1.23 \\
\hline
\end{tabular}

*Significant at .05 level. The table value required for .05 level of significance with df 24 is 2.06 .

The obtained „t" ratio value of experimental groups is higher than the table value and it is understood that both yogic practice and aerobic dance had significantly improved the performance of selected criterion variables. Since the obtained , te ratio value of experimental groups are greater than the value. The analysis of covariance on the data obtained on selected criterion variables due to the both the practices have been analyses and presented in Table III. 
TABLE -III

Analysis of Covariance Of Yogic Practices, Aerobic Dance And Control Groups On Selected Variables

\begin{tabular}{|c|c|c|c|c|c|}
\hline Variables & $\begin{array}{ll}\text { Source of } \\
\text { Variance }\end{array}$ & $\begin{array}{l}\text { Sum of } \\
\text { Squares }\end{array}$ & df & Mean Squares & $\begin{array}{l}\text { Obtained, ,Fee } \\
\text { ratio }\end{array}$ \\
\hline \multirow{3}{*}{$\begin{array}{l}\text { Cardio vascular } \\
\text { endurance }\end{array}$} & Pre Test & 356.487 & 1 & 0.0 & $0.01 *$ \\
\hline & Groups & 758.846 & 2 & 0.0 & $0.03^{*}$ \\
\hline & Error & 3725.513 & 71 & 0.0 & \\
\hline \multirow{3}{*}{$\begin{array}{l}\text { Muscular } \\
\text { endurance }\end{array}$} & Pre Test & 401.356 & 1 & 0.0 & $0.01 *$ \\
\hline & Groups & 198.048 & 2 & 0.0 & $0.03^{*}$ \\
\hline & Error & 158.004 & 71 & 0.0 & \\
\hline \multirow[t]{3}{*}{ Flexibility } & Pre Test & 505.728 & 1 & 0.0 & $0.01 *$ \\
\hline & Groups & 192.750 & 2 & 0.0 & $0.03^{*}$ \\
\hline & Error & 129.872 & 71 & 0.0 & \\
\hline \multirow{3}{*}{$\begin{array}{l}\text { Body } \\
\text { composition }\end{array}$} & Pre Iest & 19.523 & 1 & 0.0 & $0.01 \%$ \\
\hline & Groups & 55.803 & 2 & 0.0 & $0.03^{*}$ \\
\hline & Error & 14.581 & 11 & $\mathrm{U} . \mathrm{U}$ & \\
\hline
\end{tabular}

*Significant at .05 level of confidence. (The table value required for significance at .05 level with df $1 \& 71$ and $2 \& 71$ are 3.98 and 3.13 respectively).

Table III shows that the obtained F-ratio value is higher than the table value 3.13 with df 2 and 71 required for significance at .05 level. Since the value of F-ratio is higher than the table value, it indicates that there is significant difference among the adjusted post-test means of yogic practices, aerobic dance and control groups. To find out which of the three paired means had a significant difference, the Scheffe"s post-hoc test was applied and the results are presented in Table IV.

TABLE - IV

Scheffeees Test For The Differences Between The Adjusted Post Test Paired Means Of Selected Criterion Variables

\begin{tabular}{|c|c|c|c|c|c|}
\hline \multicolumn{4}{|c|}{ Adjusted Post Mean values } & \multirow[b]{2}{*}{$\begin{array}{l}\text { Mean } \\
\text { Differences }\end{array}$} & \multirow[b]{2}{*}{$\begin{array}{l}\text { Confidential } \\
\text { Interval }\end{array}$} \\
\hline Variables & $\begin{array}{l}\text { Yogic practices } \\
\text { Group }\end{array}$ & $\begin{array}{l}\text { Aerobic } \quad \text { Dance } \\
\text { Group }\end{array}$ & Control Group & & \\
\hline \multirow{3}{*}{$\begin{array}{l}\text { Cardio vascular } \\
\text { endurance }\end{array}$} & 425.91 & 448.51 & & $20.72 *$ & 5.13 \\
\hline & 425.91 & & 405.19 & $22.6^{*}$ & 5.13 \\
\hline & & 448.51 & 405.19 & $43.32 *$ & 5.13 \\
\hline \multirow{3}{*}{$\begin{array}{l}\text { Muscular } \\
\text { endurance }\end{array}$} & 26.87 & 28.42 & & $425.91 *$ & 1.06 \\
\hline & 26.87 & & 24.43 & $0 *$ & 0 \\
\hline & & 28.42 & 24.43 & $425.91^{*}$ & 0 \\
\hline \multirow{3}{*}{ Flexibility } & 29.52 & 27.76 & & $425.91 *$ & 0.96 \\
\hline & 29.52 & & 25.60 & $0 *$ & 0 \\
\hline & & 27.76 & 25.60 & $425.91 *$ & 0 \\
\hline \multirow{3}{*}{$\begin{array}{l}\text { Body } \\
\text { composition }\end{array}$} & 24.58 & 24.38 & & 425.910 & 0.32 \\
\hline & 24.58 & & 26.40 & $0 *$ & 0 \\
\hline & & 24.38 & 26.40 & $425.91 *$ & 0 \\
\hline
\end{tabular}


*Significant at .05 level.

Table IV shows that the adjusted post test means differences on selected criterion variables between the yogic practices and aerobic dance groups; The values are greater than the confidence interval value 5.13, which shows significant difference at .05 level of confidence.

The pre test, post tests and adjusted post test mean values of yogic practices, aerobic danceand control groups on selected criterion variables were graphically represented in the figure I.

FIGURE - I

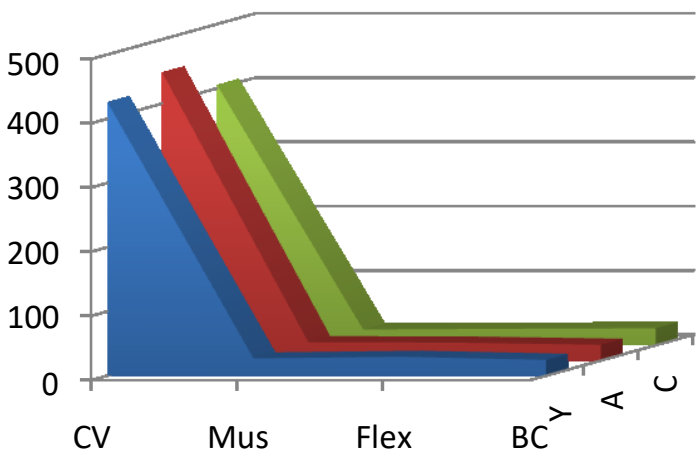

$\square$ Yogic Practice

$\square$ Aerobic dance

$\square$ Control group

FIGURE I: Mean scores of pre test, post test and adjusted post test amongyogic practices, aerobic dance dance and control groups on selected criterion variables.

\section{4. conclusion}

From the analysis of the above data, the following conclusions were drawn.

- Yogic practices group significantly improved the health related physical fitness variables.

- Aerobic dance group significantly improved the health related physical fitness variables

- Control group did not improve all the dependent variables.

- There was significant difference among the yogic practices and aerobic dance groups in improving the selected dependent variables such as cardio vascular endurance, body composition, flexibility and muscular strength/endurance.

- Aerobic dance group was found to be better in improving cardio vascular endurance and muscular strength/endurance when compared to the yogic practices group.

- Yogic practices group was found to be better in improving flexibility when compared to the aerobic dance group.

- Both yogic practices and aerobic dance groups were developed the body composition equally.

\section{Refrences}

[1] A. Tihanyi, The Effects of Guided Systematic Aerobic Dance Program on the Self Esteem of Adults, Journal of General Hospital Psychiatry, 37 (2005) 141-150.

[2] Alves, Is Aerobic Dance Good for You, Medical Journal, 8 (2008)183-183.

[3] B. Aljasir, M. Bryson, B. Al-shehri, Yoga Practice for the Management of Type II Diabetes Mellitus in Adults, Evid Based Complement Alternate Medicine, 7 (2010) 399-408.

[4] C.A. Boyle, S.P. Sayers, B.E. Jensen, S.A. Headley, T.M. Manos, The Effects of Yoga Training and A Single Bout of Yoga on Delayed Onset Muscle Soreness in the Lower Extremity, Journal of Strength Conditioning Research, 18 (2004) 723-9.

[5] D. Gallon, A.L. Rodacki, S.G. Hernandez, B. Drabovski, T. Outi, L.R. Bittencourt, A.R. Gomes, The effects of stretching on the flexibility, muscle performance and functionality of institutionalized older women, Brazilian Journal of Medical and Biological Research, 44(3) (2011) 229-235.

[6] B. Donohue, A. Miller, M. Beisecker, D. Houser, R. Valdez, S. Tiller, T. Taymar, Effects of Brief Yoga Exercises and Motivational Preparatory Interventions in Distance Runners: Results of A Controlled Trial, British Journal of Sports Medicine, 40 (2006) 60-3.

[7] A. Sarsan, F. Ardiç, M. Ozgen, O. Topuz, Y. Sermez, The effects of aerobic and resistance exercises in obese women, Clinical Rehabilation, 20 (2006) 773-82.

[8] G. Sutherland, M.B. Andersen, M.A. Stoové, Can Aerobic Exercise Training Affect Health-Related Quality of Life for People with Multiple Sclerosis? Journal of sports \& exercises psychology, 23 (2001) 122-135. 